https://dx.doi.org/10.4314/ijs.v20i2.2

Ife Journal of Science vol. 20, no. 2 (2018)

\title{
EFFECT OF ABATTOIR EFFLUENTS ON THE PHYSICOCHEMICAL PROPERTIES OF A RECEIVING WATERSHED IN AN URBAN COMMUNITY
}

\author{
Isoken H. Igbinosa ${ }^{1} *$ and Ita E. Uwidia ${ }^{2}$ \\ ${ }^{1}$ Department of Environmental Management and Toxicology, Faculty of Life Sciences, University of Benin, Private Mail \\ Bag 1154 Benin City 300001, Nigeria. \\ ${ }^{2}$ Department of Chemistry, Faculty of Physical Sciences, University of Benin, Private Mail Bag 1154, Benin City 300001, \\ Nigeria.*Corresponding author email: isoken.igbinosa@uniben.edu \\ (Received: $28^{\text {th }}$ November, 2017; Accepted: $30^{\text {th }}$ March, 2018)
}

\section{ABSTRACT}

\begin{abstract}
Abattoir effluent quality assessment is essential in providing sustainable water resource management developments. This study was carried out to assess the impact of abattoir effluent discharges on the physicochemical qualities of a receiving watershed in an urban community. Some physicochemical indicator variables of the effluent discharge and the receiving watershed were determined using standard analytical procedure. Ranges of values obtained from the study were: $\mathrm{pH}(5.79 \pm 0.66-6.58 \pm 0.46)$, electrical conductivity, $\mathrm{EC}(23.00 \pm 13.89-305.33 \pm 147.05) \mu \mathrm{S} / \mathrm{cm}$, temperature, $\mathrm{T}(29.10 \pm 1.01-29.80 \pm 0.34)^{\mathrm{i}} \mathrm{C}$, total dissolved solids, TDS $(11.33 \pm 6.65-153.00 \pm 73.72) \mathrm{mg} / \mathrm{L}$, total suspended solids, TSS $(7.50 \pm 0.78-30.93 \pm$ $5.08) \mathrm{mg} / \mathrm{L}$, alkalinity, $\operatorname{ALK}(6.10 \pm 0.00-63.03 \pm 43.81) \mathrm{mg} / \mathrm{L}$, chloride, $\mathrm{Cl}^{-}(5.91 \pm 2.04-29.57 \pm 7.38) \mathrm{mg} / \mathrm{L}$, calcium, $\mathrm{Ca}^{2+}(1.92 \pm 0.00-19.66 \pm 7.29) \mathrm{mg} / \mathrm{L}$, magnesium, $\mathrm{Mg}^{2+}(0.52 \pm 0.22-5.05 \pm 2.42) \mathrm{mg} / \mathrm{L}$, total hardness, TH $(7.47 \pm 3.32-69.92 \pm 27.37) \mathrm{mg} / \mathrm{L}$, Sodium, $\mathrm{Na}^{+}(1.71 \pm 0.18-12.86 \pm 2.29) \mathrm{mg} / \mathrm{L}$, Potassium, $\mathrm{K}^{+}(0.75 \pm 0.35-9.33 \pm 2.23) \mathrm{mg} / \mathrm{L}$, turbidity $(8.66 \pm 1.35-63.12 \pm 12.43) \mathrm{NTU}$, dissolved oxygen, DO $(1.93 \pm$ $0.41-5.86 \pm 1.00) \mathrm{mg} / \mathrm{L}$, biochemical oxygen demand, BOD $(2.80 \pm 0.60-33.06 \pm 14.36) \mathrm{mg} / \mathrm{L}$, chemical oxygen demand, COD $(14.00 \pm 2.00-60.66 \pm 12.70) \mathrm{mg} / \mathrm{L}$, sulphate, $\mathrm{SO}_{4}^{2-}(0.84 \pm 0.61-7.18 \pm 0.88) \mathrm{mg} / \mathrm{L}$, phosphate, $\mathrm{PO}_{4}^{3-}(0.01 \pm 0.00-2.10 \pm 1.22) \mathrm{mg} / \mathrm{L}$, nitrate, $\mathrm{NO}_{3}^{-}(0.37 \pm 0.42-8.70 \pm 1.33) \mathrm{mg} / \mathrm{L}$ and ammonium $\mathrm{NH}_{4}^{+}(0.02 \pm 0.01-2.46 \pm 0.78) \mathrm{mg} / \mathrm{L}$. The above data were compared with the recommended permissible limits set by the World Health Organization (WHO) and Federal Ministry of Environment (FME). Comparative correlation analysis of the effect of abattoir effluents on the receiving watershed from the studied locations revealed significant positive and negative correlations at probability value ( $p$-value) of 0.05 or 0.01 . The study revealed that the effluents discharged from the abattoir facilities pose serious health and environmental risk to communities which rely on the receiving watershed as primary source for domestic or recreation activities.
\end{abstract}

Keywords: Abattoir effluent; Pollution; Aquatic environment; Waste disposal; Water quality

\section{Introduction}

The incessant drive to increase meat production to meet the protein needs of the population is usually associated with some pollution problems (Hinton et al., 2000; Abubakar and Tukur 2014). For several years, environmental pollution of the aquatic environment has been on the increase in geometric proportion as a result of poor management practices (Osibanjo and Adie, 2007; Saidu and Musa, 2012). The pollution problems include air, water, food and soil pollution (Ezeoha and Ungwuishiwu, 2011; Abubakar and Tukur, 2014). Abattoir also known as slaughterhouse, has been defined as a premise approved and registered by the controlling authorities for hygienic slaughtering, and processing of meat for human consumption. While the slaughtering of animals results in significant meat supplies, a good source of protein and production of useful by-products such as leather, skin and bones; the processing activities involved sometimes result in environmental pollution and could result in other health hazard that may threaten human health as well as the environment (Nouri et al., 2008).

Abattoirs in developing countries especially in Nigeria are known to, directly or indirectly; pollute the environment through the various processes (Neboh et al., 2013). The meat processing industry in Nigeria has also been implicated as a major contributor to the constant pollution of the water environment, as its different untreated waste streams are often discharged into nearby watercourses (Sangodoyin and Agbawhe, 1992; Benka-Coker and Ojior, 1995; Adelegan, 2002). There is lack of treatment facilities for abattoir effluents in majority of developing countries (Obgonnaya, 2008). Inappropriate disposal 
procedure of wastes from slaughterhouses could lead to zoonotic diseases including salmonellosis, brucellosis, and helminthiasis (Cadmus et al., 1999; Neboh et al., 2013). The pollution of water bodies from abattoir effluents may result in substantial environmental and public health hazards (Coker et al., 2001; Osibanjo and Adie 2007; Neboh, et al., 2013).

Water is a vital constituent for existence of human life and the environment. The impairment in the water quality could have a detrimental effect on individual health in general. Mineral elements are essential for lives and are present within the water bodies (Versari et al., 2002; Kutlu et al., 2013). Water quality models are routinely monitored in order to ascertain the effect of biological, physical, and chemical transformation of physicochemical constituents of concern and to investigate the impact of altered boundary conditions on aquatic ecosystems (Wagenschein and Rode, 2008). Abattoir effluent discharges are a major component of water pollution, contributing to oxygen demand and nutrient loading of the water bodies, promoting toxic substance and leading to a destabilization of the aquatic environment. This study assessed the impact of abattoir effluents on the physicochemical variables of the receiving watershed.

\section{MATERIALS AND METHODS}

\section{Description of study site and sampling regime}

The receiving water body under survey is Ikpoba River, located in an urban setting within Benin City, Edo State in southwestern Nigeria. Its headwater originates from north-west of Benin City and flows north to south through the city (Benka-Coker and Ojior, 1995). The river flows through a dense rainforest where the allochthonous input of organic matter from the surrounding vegetation is derived through runoff from the surface of the soil. The Ikpoba River empties into the Benin River system. The river serves as a source of water for domestic functions, fishing and recreational purposes. The water body receives a variety of wastes ranging from industrial, agricultural, domestic and natural sources (Ekhaise and Anyasi, 2005). The abattoir wastewater runs through open drainage from the abattoir facilities to adjoining drainages in the neighbourhood without any form of treatment.

The field sampling regime was carried out, for a period of three months (February, March and April 2017). Samples were collected before 12 noon on each day of sampling at three-point stations from two abattoir facilities designated as Location 1 and Location 2. The abattoir effluent was collected from point A: the discharge point at which effluents enter the stream; point B: 50meters downstream discharge point and point $C$ : 50-meter upstream discharge point. Samples were collected in 2 liter sampling containers and transported to the laboratory within 4 to 6 hours after collection of water samples.

\section{Physicochemical analysis}

The physicochemical properties investigated include hydrogen potential activity $(\mathrm{pH})$, electrical conductivity (EC), temperature ( $\mathrm{T}$ ), turbidity, total dissolved solids (TDS), total suspended solids (TSS), total hardness (TH), alkalinity (ALK), chloride $(\mathrm{Cl})$, calcium (Ca), magnesium $(\mathrm{Mg})$, sodium $(\mathrm{Na})$, potassium $(\mathrm{K})$, dissolved oxygen (DO), biochemical oxygen demand (BOD), chemical oxygen demand (COD), sulphate $\left(\mathrm{SO}_{4}^{2}\right)$, phosphate $\left(\mathrm{PO}_{4}{ }^{3}\right)$, nitrate $\left(\mathrm{NO}_{3}\right)$ and ammonium $\left(\mathrm{NH}_{4}^{+}\right)$. Temperature was measured with a mercury-in-glass thermometer in-situ, $\mathrm{pH}$ was determined using a digital $\mathrm{pH}$ meter and turbidity was determined using turbidimeter. Total hardness was determined using ethylenediaminetetraacetic acid (EDTA) titrimetric method. Total suspended solids and total dissolved solids were both determined by gravimetric approach with a temperature ranging from 103 to $105{ }^{\circ} \mathrm{C}$ and $180{ }^{\circ} \mathrm{C}$ respectively (APHA/AWWA/WEF 1992). Chemical oxygen demand and biochemical oxygen demand were determined using the method recommended by APHA (1998). Nitrate and phosphate ions were determined using classical Kjeldahl digestion method (APHA, 1998). The soluble exchangeable ions $\left[\right.$ (chloride $(\mathrm{Cl})$, calcium $\left(\mathrm{Ca}^{2+}\right)$, magnesium $\left(\mathrm{Mg}^{2+}\right)$, sodium $\left(\mathrm{Na}^{+}\right)$and potassium $\left.\left(\mathrm{K}^{+}\right)\right]$were determined using flame atomic absorption spectrophotometer (APHA, 1998). 


\section{Data analysis}

The data generated in this study were subjected to statistical analysis using SPSS, version 21.0. Oneway analysis of variance (ANOVA) was carried out to characterize and assess the differences in physicochemical qualities on abattoir effluent quality. In order to evaluate the relationships between abattoir effluent parameters at the sampling sites, correlation analysis was conducted for the parameters in sampling stations with $p<$ 0.5 and 0.01. Duncan Multiple Range Test (DMRT) was used to determine significant difference between mean variables.

\section{RESULTS AND DISCUSSION}

Table 1 shows the values of some measured physicochemical parameters of the abattoir effluent discharges in the receiving water compared with regulatory discharge standards. Results (from the two locations) of DO, BOD and COD which are important pollution indicators were: DO (1.93 - 5.86) mg/L; BOD (2.80 - 33.06) $\mathrm{mg} / \mathrm{L}$ and COD (14.00 - 60.66) mg/L respectively. When compared with standards it showed that although DO values were within discharge limits, $\mathrm{BOD}$ and COD values were above the $\mathrm{WHO}$ standard at the discharge points in both locations 1 and 2 which indicated pollution at these points. Also TDS (11.33 - 153.00) mg/L, EC (23.00 305.33) $\mu \mathrm{S} / \mathrm{cm}$, and $\mathrm{Cl}^{-}(5.91$ - 29.57) $\mathrm{mg} / \mathrm{L}$, were above Federal Ministry of Environment (FME) standard at discharge points in locations 1 and 2 but within standards at $50 \mathrm{~m}$ upstream and downstream; turbidity was above both WHO and Federal Ministry of Environment standards. This shows that the pollution strength of the effluent was higher at the discharge point compared with upstream or downstream discharge points. Values of other parameters \{i.e. TSS $(7.50-30.93) \mathrm{mg} / \mathrm{L}$; $\mathrm{Ca}^{2+}(1.92-19.66) \mathrm{mg} / \mathrm{L} ; \mathrm{Mg}^{2+}(0.52-5.05) \mathrm{mg} / \mathrm{L}$; $\mathrm{TH}\left(7.47\right.$ - 69.92) mg/L; $\mathrm{Na}^{+}(1.71-12.86) \mathrm{mg} / \mathrm{L}$; $\mathrm{SO}_{4}^{2-}(0.84-7.18) \mathrm{mg} / \mathrm{L} ; \mathrm{PO}_{4}^{3-}(0.01-2.10) \mathrm{mg} / \mathrm{L}$; $\mathrm{NO}_{3} ;\left(0.37\right.$ - 8.70) $\mathrm{mg} / \mathrm{L}$ and $\mathrm{NH}_{4}^{+}(0.02-2.46)$ $\mathrm{mg} / \mathrm{L}\}$ were within WHO and Federal Ministry of Environment (FME) standards.

Results obtained from the correlation studies are as shown in tables $2 \mathrm{a}$ and $2 \mathrm{~b}$. Table $2 \mathrm{~b}$ depicts the correlation coefficients of the different physicochemical properties for the study period at location 1. Significant positive correlations were obtained for all the properties in both locations 1 and 2 except with DO which showed negative but significant correlations. The correlation coefficient values ranged between 0.72 and 1.00 for all the properties. However, correlation with DO which was strong but negative coefficient ' $r$ ' values ranging between 0.75 and 0.91 . The $\mathrm{pH}$ showed good but not strong correlations with some properties e.g. alkalinity, turbidity, nitrate, ammonium and COD ( $r$ values ranged from 0.33 to 0.48$)$; correlation with DO was also weak and negative $(r=-0.39)$.

Similarly, table $2 \mathrm{~b}$ shows the correlation coefficient of the different physicochemical properties for location 2. Significant positive correlations at the 0.01 and 0.05 levels (2-tailed) were obtained for all other properties except temperature and dissolved oxygen which showed negative correlation with all the physicochemical properties. The significant positive correlations had coefficient $(r)$ values between 0.65 and 1.00; negative correlations ranged from -0.29 to -0.71 for correlations between temperature and other properties; and -0.21 to -0.94 for correlations between dissolved oxygen and other properties. Relatively low $r$ values were obtained for correlations between $\mathrm{pH}$ and other properties $(r=$ $0.03-0.49) ; r$ values for $\mathrm{pH}$ and turbidity, phosphate, nitrate and COD ranged from 0.52 to 0.53 .

The physicochemical parameters of the effluents reflect diversity in the effluents characteristics at the point of discharge and after discharge. Abattoirs situated around Ikpoba river discharge their effluents into the river which is a common practice in Nigeria. A similar situation of abattoir discharge into a watercourse has been reported (Tekenah et al., 2014). Untreated abattoir effluents release high organic load which can cause deoxygenation of rivers, pollution of ground waters, severe health risks and other environmental hazards (Uwidia et al., 2017). Discharged abattoir effluents could increase nutrient levels in aquatic systems leading to eutrophication (Neboh et al., 2013). Comparative analysis of the abattoir effluents from location 1 and location 2 (Table 1) revealed a significant impact of abattoir effluent on the receiving water 
body at the point of discharge. Though BOD and COD both measured the amount of organic compounds in the water, COD is less specific, such that it measures everything that can be oxidized chemically (Sawyer et al., 2003). Increase in BOD and/or COD significantly correlates TDS, TSS, sulphate, phosphate, nitrate, nitrite and ammonia concentrations (Table $2 \mathrm{a}$ and $\mathrm{b}$ ) as a result of biodegradation activities thereby increasing turbidity with a significant decrease in dissolved oxygen. The COD was generally observed to be consistent in the upstream and downstream of the two sampled locations revealing no significant difference across respective stations. There was a decrease in nitrate and ammonia concentrations in downstream samples of the two locations when compared to upstream. This may be attributed to dilution factor downstream as the decrease was not statistically significant. However, a contrary observation has been reported by (Neboh et al., 2013), where they observed high concentration of nitrate and ammonia which was attributed to high concentration of organic matter and decomposition of protein and nitrogenous compounds.

Electrical conductivity (EC) of the sampled effluents from both locations had a considerable increase at downstream compared to upstream indicating impact of the abattoir effluents on the electrical conductivity of the river. A similar observation of increase in electrical conductivity downstream as a result of industrial and anthropogenic activities on freshwater systems has been documented (Liu et al., 2012; Drury et al., 2013; Jordaan and Bezuidenhout, 2016). Sulphate level was consistent in upstream and downstream at location 1 but a slight increase of sulphate concentration downstream of location 2 was observed. Though there was no significant difference in the sulphate concentration at upstream and downstream of the two locations but there was a significant difference at the point of discharge at both locations. There was a slight increase in phosphate concentration downstream in location 1 compared to upstream, whereas a reverse was observed in location 2. However, there was no significant difference in phosphate concentration at both locations in upstream and downstream statistically. The EC gives an indication of the ionic activity of a solution with respect to its capacity to transmit current (Yilmaz and Koc, 2014).

The TDS is a measure of the total ions in solution. In dilute solution, TDS and EC are reasonably comparable which explains why an increase in TDS was equivalent to an increase in EC (positive correlation) for both locations. As the solution becomes more concentrated (TDS $>1000 \mathrm{mg} / \mathrm{L}$, $\mathrm{EC}>2000 \mu \mathrm{S} / \mathrm{cm}$ ), the proximity of the solution ions to each other depresses their activity and consequently their ability to transmit current, although the physical amount of dissolved solids is not affected. However, at high TDS values, the ratio TDS/EC increases. Total suspended solids (TSS) refer to particles that are greater than 2 microns present in the water column. Particles less than 2 microns (average filter size) are considered as dissolved solids. Most suspended solids are made up of inorganic materials, though algae and bacteria can significantly contribute to the total solids concentration (Langland and Cronin, 2003). Total suspended solids form a major component in observing water clarity (Langland and Cronin, 2003). Turbidity refers to optical determination of water clarity (Wetzel, 2001). Turbid water appears murky or otherwise coloured, which affects the physical appearance of the water. Suspended solids and dissolved coloured material decrease water clarity by forming a hazy, opaque or muddy appearance. Turbidity measurements are frequently used as an indicator of water quality with regards to its clarity and estimated total suspended solids in water. The more solids present in the water, the less clear the water, as such, an increase in the turbidity level of water significantly correlates with an upsurge in the TSS and TDS positively.

Salt content in water also affects water clarity (Czuba et al., 2011). This is as a result of the effect of salt concentration on the settling velocity and aggregation of suspended particles. Salt ions accumulate suspended particles and muddle them together, cumulating their weights and thus increasing the likelihood of settling to the bottom which explains an upsurge in chloride content correlating with an increase in TSS, TDS, EC, BOD, COD, sulphate and other physicochemical parameters (positive correlation) in the study 
while an increase in salinity culminate in a decrease in dissolved oxygen (DO) (negative correlation). Turbidity can impede photosynthesis by preventing sunlight. Preventing photosynthesis results in decreased dissolved oxygen output and decrease in plant survival (EPA, 2012).

Chloride is usually found in wastewater and streams and may find its way into surface water from several routes (such as: wastewater from municipalities and industries, road salting, wastewater from water softening, water produced from oil and gas wells and agricultural runoff). Sulfate is a constituent of TDS and may form salts with potassium, magnesium, sodium, and other cations. Hence, increase in TDS results in an increased potassium, magnesium, and sodium concentrations. This explains why significant positive correlations exist between concentrations of potassium, magnesium, sodium, and other cations as well as other physicochemical variables in this study. This also explains why an increase in potassium, magnesium, and sodium concentrations results in a decrease in DO (negative correlation). Hard water necessitates more synthetic detergents and soap for washing and home laundry, as well as contributes to scaling in boilers and industrial equipment. Water hardness is activated by compounds of magnesium and calcium, and a variety of other metals. Hence, an increase in concentrations of calcium and magnesium resulted in water hardness as revealed in this study (positive correlation). The dissolved oxygen (DO) was low at the abattoir effluent discharged point at both locations and showed significant difference across upstream and downstream. Dissolved oxygen level which is too low or too high can affect water quality and impair aquatic life. Too high or too low amount of DO could be responsible for the negative correlation of DO towards other parameters observed in this study. Dissolved oxygen has been shown to affect bacterial community composition in aquatic ecosystem (Jordaan and Bezuidenhout, 2016).

\section{CONCLUSION}

Physicochemical parameters are the significant determinants of water quality that directly or indirectly affects its use. Findings from this study reveal variation in these parameters in the receiving water body, where significant differences were observed in the analyzed parameters. It was observed that the discharged effluents in the receiving water fell short of standard requirements that are critical to the provision of clean and safe water, which revealed that the receiving water was polluted due to effluents from abattoir facilities in the community. This could pose significant health and environmental threat to rural communities which rely on the receiving water as their source of domestic water. Without any water treatment, the use of such water could impair the quality of surface and groundwater resources in the environment. Overall, continuous monitoring must be employed to control pollution from the abattoir facilities. 


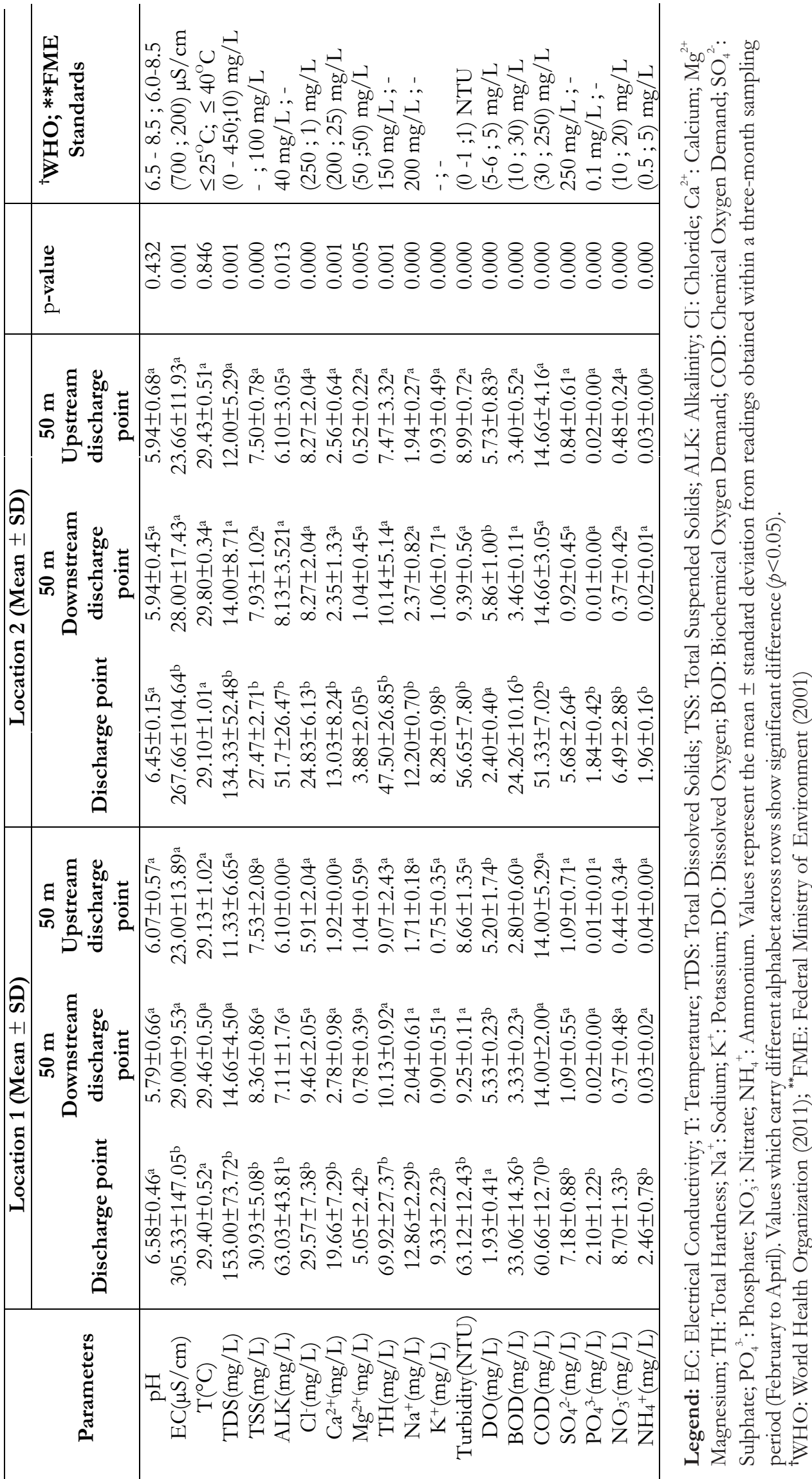




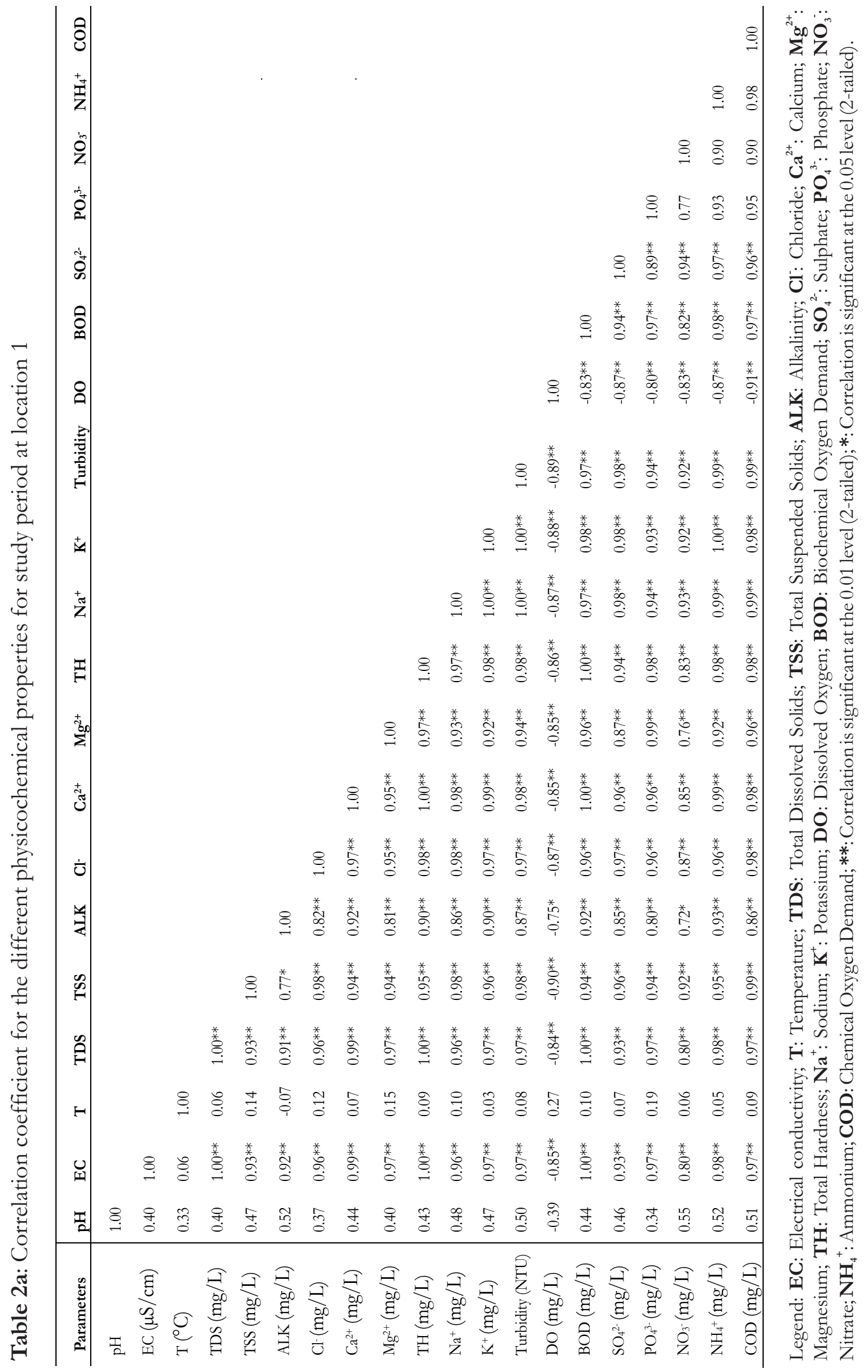




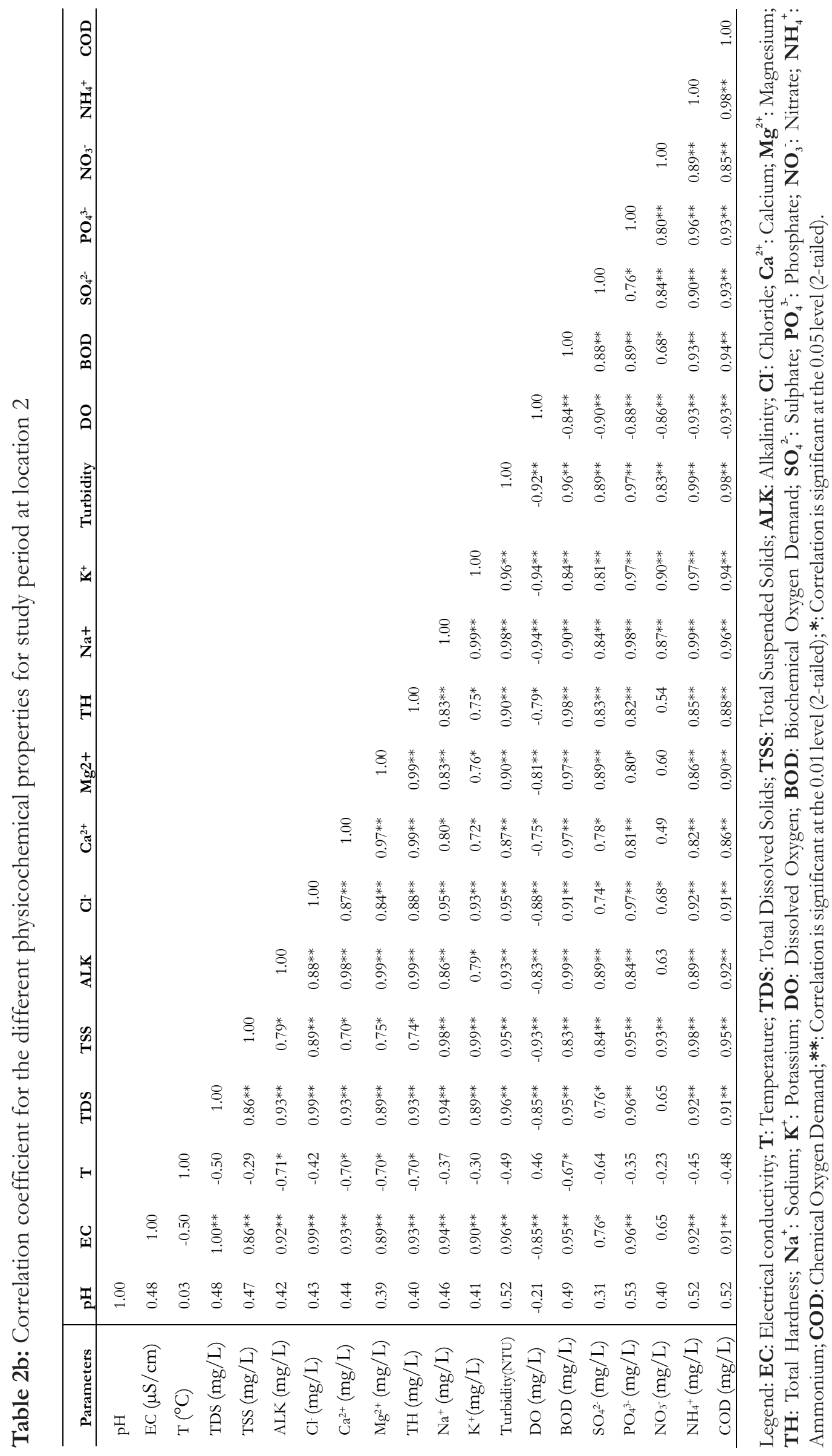




\section{REFERENCES}

Abubakar, G.A., Tukur, A. (2014). Impact of abattoir effluent on soil chemical properties in Yola, Adamawa State, Nigeria. International Journal of Sustainable Agricultural Research 1(4): 100-107.

Adelegan, J.A. (2002). Environmental policy and slaughterhouse waste in Nigeria. Proceedings of the 28th WEDC Conference, Calcutta, India, 2002, pp. 3-6.

American Public Health Association (APHA) (1998). Standard methods for examination of water and wastewater. American Public Health Association, American Water Works Association and Water Environment Federation. 20th edn. Washington DC, USA, 1998, pp. 5-7.

APHA/AWWA/WEF (1992). Standard methods for the Examination of water and wastewater, American Public Health Associations, American water works Association, Water Environment Federation Greenberg, AE; Clesceri, L S; Eaton, A D (eds.) 18th Edition.

Benka-Coker, M.O., Ojior O.O. (1995). Effect of slaughterhouse wastes on the quality of Ikpoba River, Benin City, Nigeria. Bioresource Technology 52: 5-12.

Cadmus, S.I., Olugasa, B.O., Ogundipe, G.A. (1999). The prevalence and zoonotic importance of bovine tuberculosis in Ibadan," in Proceedings of the 37th Annual Congress of the Nigerian Veterinary Medical Association, pp. 65-70.

Coker, A.O., Olugasa, B.O., Adeyemi, A.O. (2001). Abattoir and wastewater quality in South Western Nigeria. In Proceedings of the 27 th Water, Engineering and Development Centre Conference, Lusaka, Zambia, 2001.

Czuba, J.A., Magirl, C.S., Czuba, C.R., Grossman, E.E., Curran, C.A., Gendaszek, A.S., Dinicola, R.S. (2011). Comparability of suspended-sediment concentration and total suspended solids data sediment load from major rivers into Puget Sound and its adjacent waters. USGS Fact Sheet 20113083. Tacoma, WA: US Geological Survey.

Drury, B., Rosi-Marshall, E., Kelly, J.J. (2013). Wastewater treatment effluent reduces the abundance and diversity of benthic bacterial communities in urban and suburban rivers. Applied and Environmental Microbiology 79(6):1897-1905.

Ekhaise, F.O., Anyasi, C. (2005). Influence of breweries effluent discharge on the microbiological and physicochemical quality of Ikpoba River, Nigeria. African Journal of Biotechnology 4(10): 1062-1065.

EPA (2012). Channel Processes: Suspended Sediment Transport. In Water: Science and Technology. (http://water.epa. gov/scitech/datait/tools/warsss/suspen d.cfm).

Ezeoha, S.L., Ungwuishiwu, B.O. (2011). Status of abattoir wastes research in Nigeria. Journal of Environmental Technology 30(2):1-6.

FME (Federal Ministry of Environment), (2001). National guideline and standard for water quality in Nigeria, pp: 114.

Hinton, M.H., Mead, G.C., Rowlings, C. (2000). Microbiological control in meat industry. Flair flow Europe technical manual. F-Fe 339A/00. (www.exp-ie/flair.html).

Jordaan, K., Bezuidenhout, C.C. (2016). Bacterial community composition of an urban river in the North West Province, South Africa, in relation to physicochemical water quality. Environmental Science and Pollution Research 23: 5868-5880.

Kutlu, B., Can, S.S.S., Serdar, O., Seker, S. (2013). Assessment of water quality by physicochemical parameters for Munzur and Peri River, Turkey. Pollution 56: 1345613459.

Langland, M., Cronin, T. (2003). A summary report of sediment processes in Chesapeake Bay and Watershed. In waterresources investigations report 03-4123. New Cumberland, PA: US Geological Survey. (http: / / pa.water.usgs. gov/reports/wrir03-4123.pdf).

Liu, Z., Huang, S., Sun, G., Xu, Z., Xu, M. (2012). Phylogenetic diversity, composition and distribution of bacterioplankton community in the Dongjiang River, China. FEMS Microbiology and Ecology 80(1): 3044.

Neboh, H.A., Ilusanya, O.A., Ezekoye, C.C., Orji, F.A. (2013). Assessment of Ijebu-Igbo 
abattoir effluent and its impact on the ecology of the receiving soil and river. Journal of Environmental Science, Toxicology and Food Technology 7(5): 61-67.

Nouri J, Karbassi AR, Mirkia S (2008). Environmental management of coastal regions in the Caspian Sea. International Journal of Environmental Science and Technology 5(1): 43-52.

Obgonnaya, C. (2008). Analysis of groundwater pollution from abattoir waste in Minna, Nigeria. Research Journal of Dairy Science 2(4): 74-77.

Osibanjo, O., Adie, G.U. (2007). Impact of effluent from Bodija abattoir on the physicochemical parameters of Oshunkaye stream in Ibadan City, Nigeria. African Journal of Biotechnology 6(15): 18061811.

Saidu, M., Musa, J.J. (2012). Impact of abattoir effluent on River Landau, Bida, Nigeria. Journal of Chemical, Biological and Physical Sciences Sec. A 2(1): 132-136.

Sangodoyin, A.Y., Agbawhe, O.M. (1992). Environmental study on surface and groundwater pollutants from abattoir effluents. Bioresource Technology 41: 193-200.

Sawyer, C.N., McCarty, P.L., Parkin, G.F. (2003). Chemistry for Environmental Engineering and Science (5th ed.). New York: McGraw-Hill.

Tekenah, W.E., Agi, P.I., Babatunde, B.B. (2014). Analysis of surface water pollution from abattoirs and the interrelationship between physicochemical properties (A case study of the New Calabar River). Journal of Environmental Science, Toxicology and Food Technology 8(5): 10-18.

Uwidia, I.E., Oghenneovo, S., Jatto, E.O. (2017). Physicochemical evaluation of abattoir wastewater from an abattoir in Benin City. Mambilla: Journal of Sciences and Environment 4(1):23-27

Versari, A., Parpinello, G.P., Galassi, S. (2002). Chemometric survey of Italian bottled mineral waters by means of their labelled physicochemical and chemical composition. Journal of Food Composition and Analysis 15: 251-264.

Wagenschein, D., Rode, M., (2008). Modelling the impact of river morphology on nitrogen retention-a case study of the Weisse Elster River (Germany). Ecological Modelling 211: 224- 232

Wetzel, R.G. (2001). Limnology: Lake and River Ecosystems (3rd ed.). San Diego, CA: Academic Press.

WHO (World Health Organization), (2011). Guidelines for drinking-water quality (4th ed.). Geneva: World Health Organization.

Yilmaz, E., Koc, C. (2014). Physical and chemical evaluation for the water quality criteria in a farm on Akcay. Journal of Water Resource and Protection 6: 63-67. 